\title{
Overpressures: Causal Mechanisms, Conventional and Hydromechanical Approaches
}

\author{
D. Grauls ${ }^{1}$ \\ 1 Elf Exploration Production, Évaluation du pétrole et modélisation du bassin, Avenue Larribau, 64000 Pau - France \\ e-mail: grauls@elf-p.fr
}

\begin{abstract}
Résumé - Surpressions : origine, approches conventionnelle et hydromécanique - On rencontre souvent des régimes anormaux de pression dans les bassins sédimentaires. Les relations entre la contrainte verticale effective et la porosité ont été appliquées, depuis 1970, dans la région de la Gulf Coast, afin d'évaluer ces surpressions. Des résultats ont été obtenus en faisant appel à la sismique et à la modélisation de bassin dans les bassins tertiaires de sable argileux à contrainte verticale dominante et en déséquilibre de compaction. Cependant, les surpressions d'origines différentes et/ou additionnelles (contrainte tectonique, génération d'hydrocarbures, contrainte thermique, transfert lié aux failles, fracturation hydraulique) ne peuvent pas être quantifiées en utilisant cette approche.

En plus des méthodes conventionnelles, une approche hydromécanique est proposée. Pour toute profondeur, la limite supérieure est contrôlée par les conditions de fracturation hydraulique ou par la réactivation de failles. La fracturation hydraulique suppose un système ouvert par période, en régime de contrainte effective mineure proche de zéro. Une connaissance approfondie des régimes de contraintes tectoniques actuels permet une estimation directe de l'évolution de la contrainte minimale. Une évaluation quantitative de la pression avec la profondeur est donc possible, puisque dans les systèmes géologiques compartimentés et/ou non drainés, les régimes de pression, quelles que soient leurs origines, ont tendance à atteindre rapidement une valeur proche de la contrainte principale mineure. Ainsi, l'évaluation de la surpression sera améliorée, puisque cette méthodologie peut être appliquée à divers environnements géologiques où les surpressions ont d'autres origines, les mécanismes étant souvent combinés.

Cependant, les tendances de l'évolution de pression dans les zones de transition sont plus difficiles à évaluer de façon correcte. Une recherche complémentaire sur les couvertures et les fermetures sur faille est donc nécessaire pour améliorer leur prévision. En plus de l'évaluation de la surpression, le concept de contrainte principale mineure permet de mieux appréhender le système pétrolier. En effet, les transferts d'hydrocarbures liés aux failles, les domaines de fracturation hydraulique et l'étanchéité du recouvrement dépendent d'une interaction subtile, dans le temps, entre la surpression et les régimes de contrainte principale mineure.
\end{abstract}

Mots-clés : surpressions, contrainte mineure, fracturation hydraulique, transfert par faille, propriétés mécaniques.

\footnotetext{
Abstract-Overpressures: Causal Mechanisms, Conventional and Hydromechanical ApproachesAbnormal fluid pressure regimes are commonly encountered at depth in most sedimentary basins. Relationships between effective vertical stress and porosity have been applied, since 1970 to the Gulf Coast area, to assess the magnitude of overpressures. Positive results have been obtained from seismic and basin-modeling techniques in sand-shale, vertical-stress-dominated tertiary basins, whenever compaction disequilibrium conditions apply. However, overpressures resulting from other and/or additional causes (tectonic stress, hydrocarbon generation, thermal stress, fault-related transfer, hydrofracturing...) cannot be quantitatively assessed using this approach.
} 
A hydromechanical approach is then proposed in addition to conventional methods. At any depth, the upper bound fluid pressure is controlled by in situ conditions related to hydrofracturing or fault reactivation. Fluid-driven fracturing implies an episodically open system, under a "close to zero" minimum effective stress regime. Sound knowledge of present-day tectonic stress regimes allows a direct estimation of minimum stress evolution. A quantitative fluid pressure assessment at depth is therefore possible, as in undrained or/and compartmented geological systems, pressure regimes, whatever their origin, tend to rapidly reach a value close to the minimum principal stress. Therefore, overpressure assessment will be improved, as this methodology can be applied to various geological settings and situations where present-day overpressures originated from other causal mechanisms, very often combined.

However, pressure trends in transition zones are more difficult to assess correctly. Additional research on cap rocks and fault seals is therefore required to improve their predictability. In addition to overpressure assessment, the minimum principal stress concept allows a better understanding of petroleum system, as fault-related hydrocarbon dynamic transfers, hydrofractured domains and cap-rock sealing efficiency depend on the subtle interaction, through time, between overpressure and minimum principal stress regimes.

Keywords: overpressure, minimum stress, hydrofracturing, fault transfer, mechanical properties.

\section{INTRODUCTION}

The study of overpressures in petroleum exploration started in 1970 in offshore Gulf Coast areas. Some conventional methods, essentially based on empirical porosity versus effective vertical stress relationships, have been applied worldwide with some success, in sand-shale Tertiary basins whenever compaction disequilibrium was the main causal mechanism. The failure of some pressure predictions, and the recent evolution of petroleum exploration towards deeper targets in tectonically complex basins (North Sea for instance), and in frontier areas (deep offshore areas), led us to review overpressure assessment and to propose some complementary approaches, to be used in addition to conventional approaches. A rapid review of the causes of overpressuring was first carried out in order to rank the main causal mechanisms and to evaluate their relative contributions. That was used as background for proposing, in a second stage, another quantitative approach to assess abnormal pressure regimes at depth. This hydromechanical approach, called "minimum stress approach", was based on the knowledge of the in situ minimum principal stress $\left(S_{3}\right)$ versus depth profile. The applicability of this approach was illustrated using case studies where the present-day overpressure regimes originated from different causal mechanisms, very often coupled together, and where the contribution of each phenomenon cannot always be correctly identified and assessed.

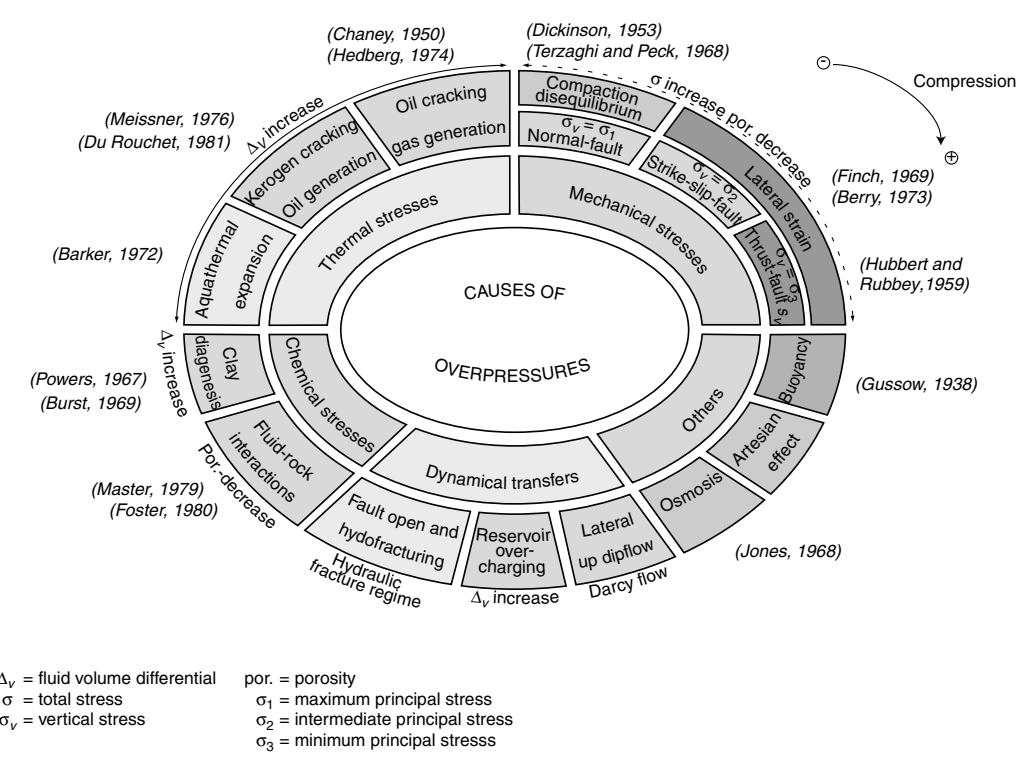

Figure 1

Main overpressure causal mechanisms (Grauls, 1997). 


\section{CAUSES, CONTRIBUTIONS, AND CONVENTIONAL ASSESSMENT OF OVERPRESSURES}

The general overview of the different causal mechanisms and their relative contributions to the present day overpressure regime is supported by different key publications (Fertl, 1976; Magara, 1978), the recent research onto overpressures (Osborne and Swarbrick, 1997) and the in-house results on hydrofracturing and in situ minimum stress evaluation. As shown on Figure 1, and by order of importance: mechanical stresses, thermal effect, dynamic transfers, and chemical stresses are believed to be the main factors in generating abnormal pressures in present-day hydrocarbon systems.

\subsection{Mechanical Stress}

In recent sand-shale dominated Tertiary basins, the weight of overburden or vertical stress $\left(S_{v}\right)$ contributes to the development of overpressures in poorly drained, low permeability shale-prone intervals. Since Dickinson (1953), the compaction disequilibrium phenomena has been considered by many authors as the main cause of overpressuring in sedimentary basins (Fertl, 1976; Magara, 1978). The magnitude of this pressure regime was quantitatively assessed from soil mechanics principles developed by Terzaghi (1968). Empirical approaches or porosity versus vertical effective stress relationships (Mann and Mackensie, 1990) have been developed (Fig. 2). Other empirical relationships are still used for predicting abnormal pressures before drilling, from low frequency, seismic-derived interval velocities (Grauls et al., 1995). The success ratio obtained from seismic predictions, was close to $65 \%$ considering a relative uncertainty on overpressure estimate (OVP) less than or equal to $10 \%$ (delta OVP/OVP < or $=0.1$ ). The success of this methodology depends on the following conditions:

- recent Tertiary sedimentary basins, without any major discontinuity or unconformity;

- oedometric conditions, vertical stress dominated contexts, without any lateral strain;

- compaction disequilibrium only, without any additional contributions.

The contribution of present day lateral stresses or compressive tectonics, as a possible overpressure mechanism, is rarely considered and remains strongly underestimated, despite the considerations made by Hubbert and Rubey (1959) in thrust-fault contexts, as well by Finch (1969), Berry (1973) and Grauls and Baleix (1993) in strike-slip fault contexts, where $S_{v}$ becomes the intermediate stress $\left(S_{2}\right)$.

\subsection{Thermal Stress}

The volumetric expansion of water or "aquathermal effect" was proposed as a main overpressuring mechanism by Barker (1972). However, recent work carried out by Luo and Vasseur (1992) concluded in poor contribution of this mechanism (less than $5 \%$ of total overpressuring). The transformation from kerogen to oil, or primary cracking, occurring at temperatures ranging from 100 to $120^{\circ} \mathrm{C}$, was proposed by Meissner (1978) and Du Rouchet (1978) as a potential overpressure generating mechanism. Secondary oil cracking, related to the "oil to gas" transformation, occurring at temperatures exceeding $175-180^{\circ} \mathrm{C}$, was also believed by

$\sigma_{1}$
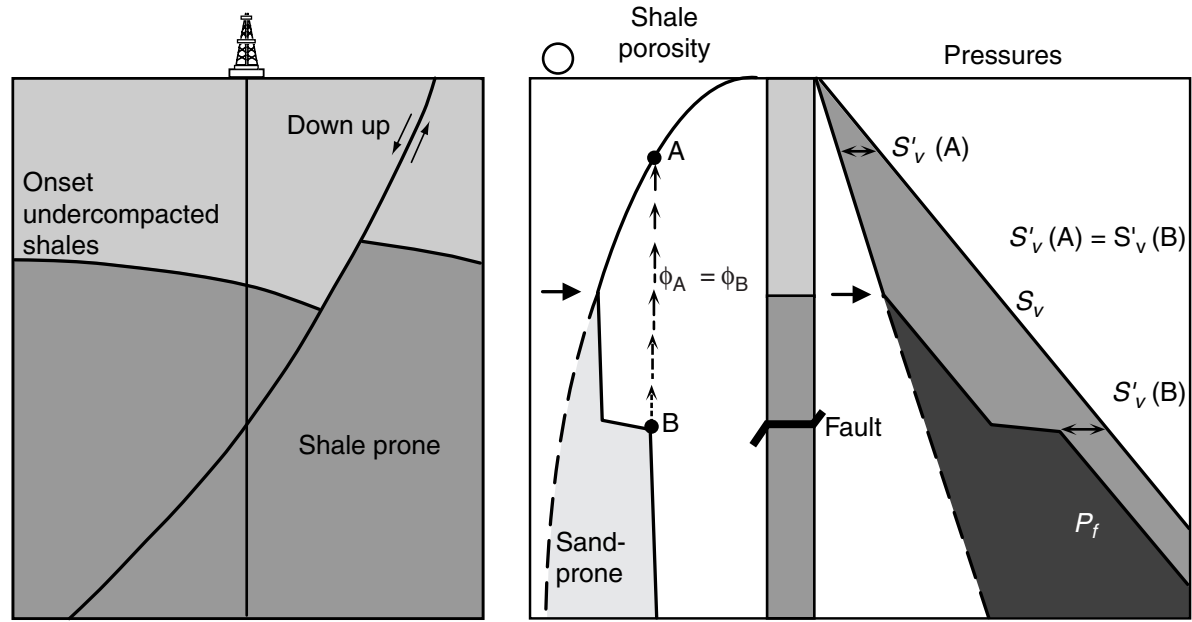

Figure 2

General principles of conventional methodologies applied to quantify the overpressures related to compaction disequilibrium phenomena. This approach is based on porosity versus vertical effective stress relationship: the fluid pressure $\left(P_{f}\right)$ at depth $B$ can be assessed knowing the vertical effective stress $\left(S_{v}^{\prime}\right)$ at depth $A$, as the porosities in $A$ and $B$ are equivalent. 
some authors (Hedberg, 1974) to contribute to pressure build-up. This theoretically possible contribution has not been truly demonstrated in field case studies. However, the gas generation phenomena, associated with compaction disequilibrium, was believed to contribute as a secondary causal mechanism to the present-day overpressure regime in the HP-HT area of the Central North Sea, United Kingdom sector (Osborne and Swarbrick, 1997). In summary, overpressuring very likely developed during kerogen-to-oil and oil-to-gas transformations in source rock layers. However, this thermal effect depends on time, source rock potential, facies and drainage efficiency, and is still not well assessed in quantitative terms. Conversely, the aquathermal effect poorly contributes to the overpressure system.

\subsection{Dynamic Transfers}

Overpressures, generated most often below $3000 \mathrm{~m}$, play a key role in secondary hydrocarbon migration, and more generally in fluid dynamic transfers. Such dynamic processes can be related to conventional lateral Darcy flow, as observed in large-scale tilted reservoir units (Gullfaks field in offshore Norway for instance). The pressure gradient reaches its maximum at the top of the hydrocarbon column, at the highest structural closure, and decreases downdip with depth. The overpressure regime tends to be homogeneous within the same pressure cell. This "lateral transfer" related overpressuring was emphasized by Traugott (1996) and more recently reviewed by Yardley (1999, in press).

Dynamic transfers can be related also to vertical hydraulic flow. Hydrofracturing, and open fault zones act as preferential pathways for hydrocarbon migration (Grauls and Cassignol, 1992; Grauls and Baleix, 1993). Such mechanisms can only account for the large volumes of hydrocarbons transferred to shallow depths from deeper sources, in a very short period of geological time. Abnormal fluid pressures are localized within dilatant faults or fracture networks, rather than in the rock matrix itself. Fluid pressure values twice the normal hydrostatic regime are commonly encountered.

Fluids are vertically and laterally transferred to reservoirs when intersecting fault discontinuities. Pressure regimes are likely to increase in response to this "overcharging" (Grauls and Baleix, 1993). The additional pressure value will depend on fluid volume, charging rate, reservoir extension or drainage efficiency, pore and fluid compressibility.

If the overpressure regime due to lateral updip flow can be quantitatively well assessed, the other causes linked to open fracturing, active fault and overcharging cannot be evaluated by conventional approaches and are very rarely taken into account.

\subsection{Chemical Stress}

Overpressuring related to clay or smectite-illite transformation was formerly believed to be induced by the volumetric increase of free water in low matrix-permeability sediments (Burst, 1969). That causal mechanism was recently revised by Harrison and Summa (1990), and Swarbrick and Osborne (1996). They concluded that less than $5 \%$ of the total pressure regime generated in undercompacted sediments can be accounted for by clay diagenesis. "Pressure-solution" mechanisms and more generally, fluid-rock interactions can lead to a reduction of petrophysical characteristics, and therefore, to pressure buildup relative to the reduced pore space. However, the effect of chemical stress on overpressure development is very complex and therefore very poorly assessed.

\subsection{Others Causes}

The effects of osmosis, artesian trapping, and buoyancy have been evaluated since a long time and are well assessed.

\subsection{Summary}

Compaction disequilibrium is likely the most important causal mechanism for overpressure development in recent, vertical-stress dominated, sand-shale sedimentary basins. All present-day Tertiary basins, that have developed worldwide in deltaic environments (Niger, Mississippi, Nile, Mahakam Deltas), or in offshore passive margins (West African, North and South American margins for instance) are therefore concerned. In these specific contexts, the conventional approaches developed in United States Gulf Coast since 1968 continue to be applied with some success. However, important limitations must be emphasized. These are related to:

- mechanical assumptions (vertical stress dominated context, oedometric lateral boundary conditions);

- the irreversibility of sediment compaction process;

- the complex basin histories (major unconformities, uplifts, stress regime changes);

- the existence of additional causal mechanisms (lateral stresses, thermal effect, dynamic transfers, etc.);

- the existence of several causes combined together in the same geological area, making the "global" present-day abnormal pressure regime very difficult to assess.

\section{AN APPROACH BASED ON LEAST PRINCIPAL STRESS}

Taking into account the above-mentioned limitations, a new approach is proposed as a complement to conventional methods. General observations made worldwide in various HP contexts below $3000 \mathrm{~m}$ showed that the upper limit of abnormal pressures, whatever their causal mechanisms, seems to be controlled by a critical threshold $P_{c}$, such as: $0.75 * S_{v}<P_{c}<0.95 * S_{v}$, where $S_{v}$ corresponds to the vertical total stress. What does this threshold imply? Which 
mechanisms control the magnitude of maximum fluid pressures at depth? They are most likely the most important questions to be addressed. Maximum fluid-pressure values in rock masses are effectively limited at depth by the hydrofracturing or hydraulic fracture reactivation conditions.

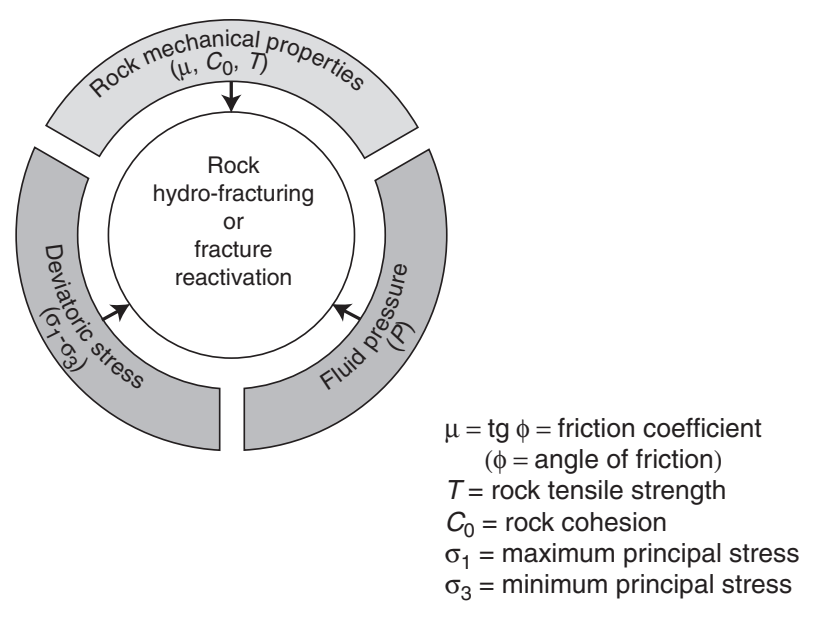

The creation of dilatant fracture permeability allows the excess fluid pressure to be transiently dissipated (Sibson, 1981). These hydrofracturing conditions depend upon three main parameters:

- Fluid pressure magnitude, independent of causal mechanisms.

- Rock mechanic properties (cohesion, rock tensile strength, and friction angle). As displayed on the Mohr-Coulomb type diagram (shear versus effective normal stress) in
Figure $3 \mathrm{a}$, at constant deviatoric stress, the fluid pressure increase favors the failure or the reactivation of preexisting fractures. Shear failure (mode II) preferentially occurs in low mechanical-property soft rocks (clays, chalk, salt, etc.). Oppositely, a tensile fracture (mode I) is favored in well consolidated, hard rocks (cemented sandstone, compact limestone, etc.).

- The deviatoric stress or the difference between maximum and minimum principal stresses $\left(S_{1}-S_{3}\right)$. At constant rock properties, or at equivalent rock failure envelop (Fig. 3b), high differential or deviatoric stress favors shearing or mode II, and low deviators tensile or mode I fracturing. All intermediates between mode I and II are also possible (shear dilatancy).

This hydromechanic approach clearly shows that, despite the difference between the mode of failure (I, II or I-II), the conditions at which the hydrofracturing occurs are such that the minimum effective stress is close to $0: S_{3}-P_{f}=\mathrm{I} \varepsilon \mathrm{I}$. Therefore, sound knowledge of the in situ minimum principal stress $S_{3}$ allows direct quantitative assessment of fluid pressures developed in undrained systems at depth, whatever their causal mechanisms.

As shown on Figure 4, the regional least principal stress profile can be well constrained both by the maximum fluid pressure values (lower bound) and by the minimum leak off pressure values (upper bound corresponding to the fracture initiation or reactivation at well bore)

This present day $S_{3}$ profile depends also on the tectonic stress regime (Grauls, 1997) and can be well assessed quantitatively using the following power law equation (Fig. 5):

$$
S_{3}=S_{3 s f}+0.0055 *\left(Z-Z_{s f}\right)^{n}
$$
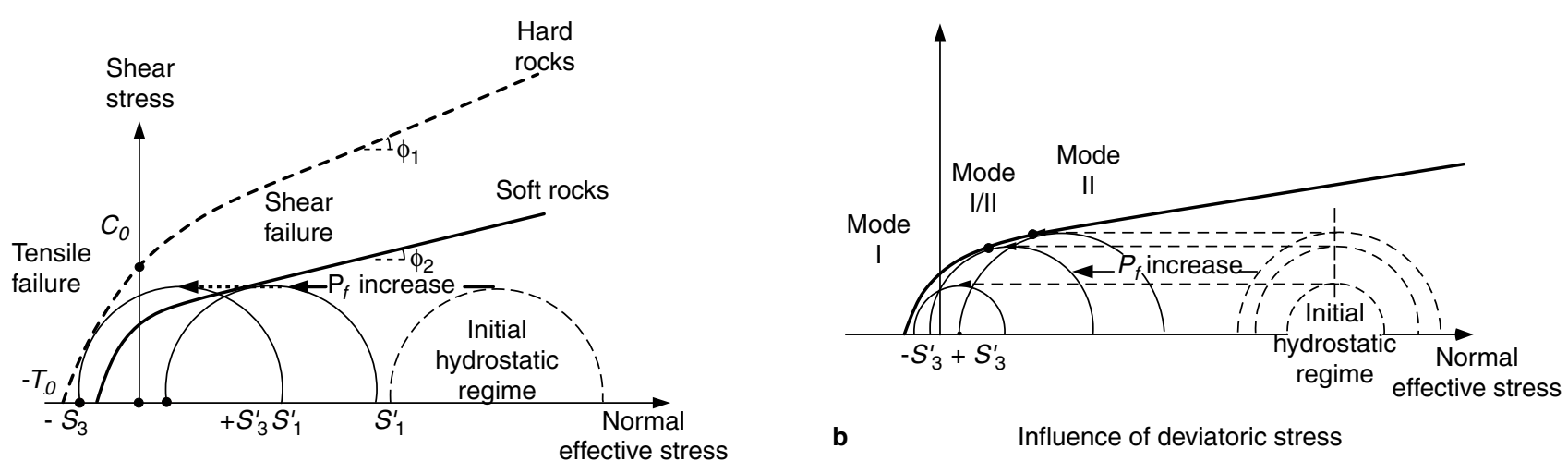

b

Influence of deviatoric stress

a Influence of rock mechanical properties

Figure 3

As Fluid pressure $\left(P_{f}\right)$ increase up to hydraulic failure, the mode of rupture in tensile (mode I) or in shear (mode II) conditions is depending on rock mechanical properties (Fig. 3a), and deviatoric stress (Fig. 3b). $T=$ rock tensile strength; $C=$ rock cohesion, $\phi=$ friction angle; $S_{1}^{\prime}=$ maximum principal effective stress; $S_{3}^{\prime}=$ minimum effective stress. 


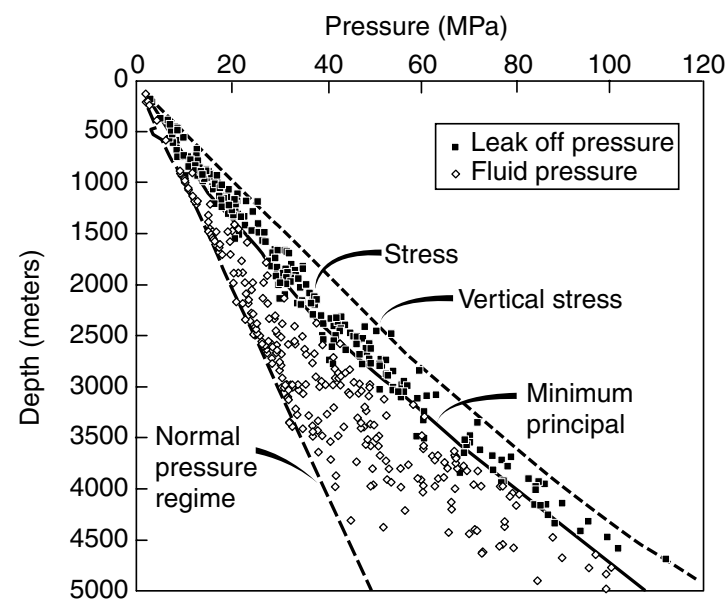

Figure 4

Minimum principal stress assessment in a Norwegian North Sea area using fluid pressure and leak off pressure records: the far field least principal stress profile is constrained both by the maximum fluid pressure values (lower bound) and by the minimum leak off pressure values (upper bound corresponding to the fracture initiation or reactivation at well bore).

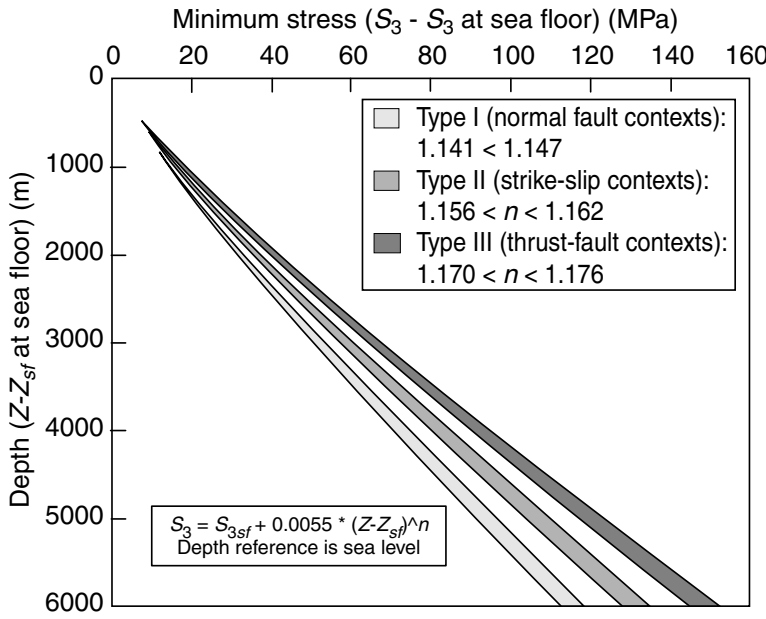

Figure 5

Evolution of minimum principal stress as function of depth and tectonic stress regimes. $S_{3}$ and $S_{3 f}$ are the minimum principal stress values at depths $Z$ and at sea floor $Z_{f}$, respectively. The $n$ exponent is dependent on the tectonic stress regime.
$S_{3}$ is the minimum principal stress value at depth $Z$, expressed in megapascals (MPa).

$S_{3 s f}$ corresponds to the minimum principal stress value at sea floor $\left(Z_{s f}\right)$, or to the pressure of water column, and is expressed in MPa:

$-Z$ : the vertical depth, expressed in meters (m) and referred to sea level;

$-Z_{s f}:$ the depth at sea floor, expressed in $\mathrm{m}$ and referred to sea level;

$-n$ : exponent of the power law function, is depending on the tectonic stress regime:

- $1.141<n<1.147$ in type I context, $S_{v}=S_{1}$ (offshore passive margins, deltas, normal faulted contexts);

- $1.156<n<1.162$ in type II context, $S_{v}=S_{2}$ (offshore strike slip faulted contexts);

- $1.170<n<1.176$ in type III context, $S_{v}=S_{3}$ (thrust faulted, fully compressive contexts).

\section{APPLICATIONS}

This methodology can be applied to different geological settings, for various lithological facies, and is particularly well suited to HP domains and confined systems, characterized by low drainage efficiency. Abnormal pressure regimes induced by lateral stress effect, by thermal expansion of source rock kerogen, or by multiple causes (overcharging, dynamic transfers, compartmenting, etc.) will be considered.

\subsection{Lateral Stress Effect}

Conventional methods can applied in sedimentary basins, provided that oedometric or zero-lateral-strain conditions are filled. Such specific conditions are not actually encountered in many places. Some of them are known as compressive domains (Azerbaidjan, Zagros, Rocky Mountains, Caribbean Islands, South China Sea, etc.), but others are less characteristic, because strike-slip fault tectonics is more difficult detected on seismic data. This type of tectonics, intermediate between thrust and normal faulted regimes, is very likely underestimated, especially at great depth in multiphase basins and in deep offshore areas. Lateral confining stresses are believed to play a key role in overpressure development, especially under undrained shearing conditions (Yassir, 1994). Hydrofracturing processes also seem to be very often associated with strike-slip faulting or fully compressive tectonics (Grauls and Cassignol, 1992). At a given depth, the evolution towards more compressive contexts causes the $S_{3}$ value to increase, as highlighted on Figure 5. The maximum fluid pressure value, as controlled by $S_{3}$, builds up accordingly. For instance, the maximum pressure regimes expected at $3000 \mathrm{~m}$ depth in Niger Delta (normal fault, type I), offshore Brunei (strike-slip, type II) and offshore Azerbaidjan (fully compressive, type III), reach about 53, 60 and $65 \mathrm{MPa}$ respectively. The contribution of this effect in terms of overpressure in strike-slip and thrust fault tectonics is 30 and $50 \%$ respectively in excess of what it can be expected in conventional normal fault, type I contexts (Fig. 5). Therefore, sound knowledge of present day tectonic 
regimes at depth, should allow a better quantitative assessment of the contribution of lateral strain.

\subsection{Hydrocarbon Generation}

Thermal expansion of kerogen (Du Rouchet, 1978; Meissner, 1981; Spencer, 1987), or secondary cracking of oil at higher temperatures (Osborne and Swarbrick, 1997) have been mentioned as possible causes of abnormal pressure regimes in sedimentary basins. The pressure anomaly is frequently associated with microfracturing, indicating that the hydrofracturing threshold has been reached. This causal mechanism is illustrated in case studies from the Williston basin, and from offshore Angola.

\subsubsection{Williston Basin - North Dakota}

This case deals with a pressure anomaly recorded within the "Bakken shales" formation, Devonian age source rocks, in the Williston basin, North Dakota (Meissner, 1978). As shown on Figure 6 (adapted from Meissner), an overpressure cell developed below $10000 \mathrm{ft}$. That depth corresponds to the onset of oil generation, as indicated by present-day temperature values ranging from 100 to $120^{\circ} \mathrm{C}$, and vitrinite reflectance values between 0.6 and $0.7 \%$. The pressure versus depth profile obtained from test records (Fig. 6) indicates that normal hydrostatic conditions (0.46$0.47 \mathrm{psi} / \mathrm{ft}$ ) apply down to the total depth, except within the Devonian source-rock interval (10 to $11000 \mathrm{ft}$ ), where an abnormal pressure gradient reaches $0.73 \mathrm{psi} / \mathrm{ft}\left(1.64 \mathrm{~g} / \mathrm{cm}^{3}\right.$ EMW). This Bakken formation is both a reservoir and source rock. The excellent reservoir characteristics are provided by hydrofracture-induced permeability. Compaction is normal with regards to the rock history, and compaction disequilibrium do not apply. As shown on Figure 6, the $53 \mathrm{MPa} S_{3}$ value predicted from the type I stress profile (vertical stress dominated tectonic regime) agrees well with the $51 \mathrm{MPa}$ pressure value recorded at $3000 \mathrm{~m}$ depth.

\subsubsection{Offshore Angola}

This in-house case study from offshore Angola shows a similar pattern (Fig. 7). A high pressure anomaly developed within the Senonian source-rock interval at depths ranging from 2400 to $2550 \mathrm{~m}$. The pressure gradient recorded from
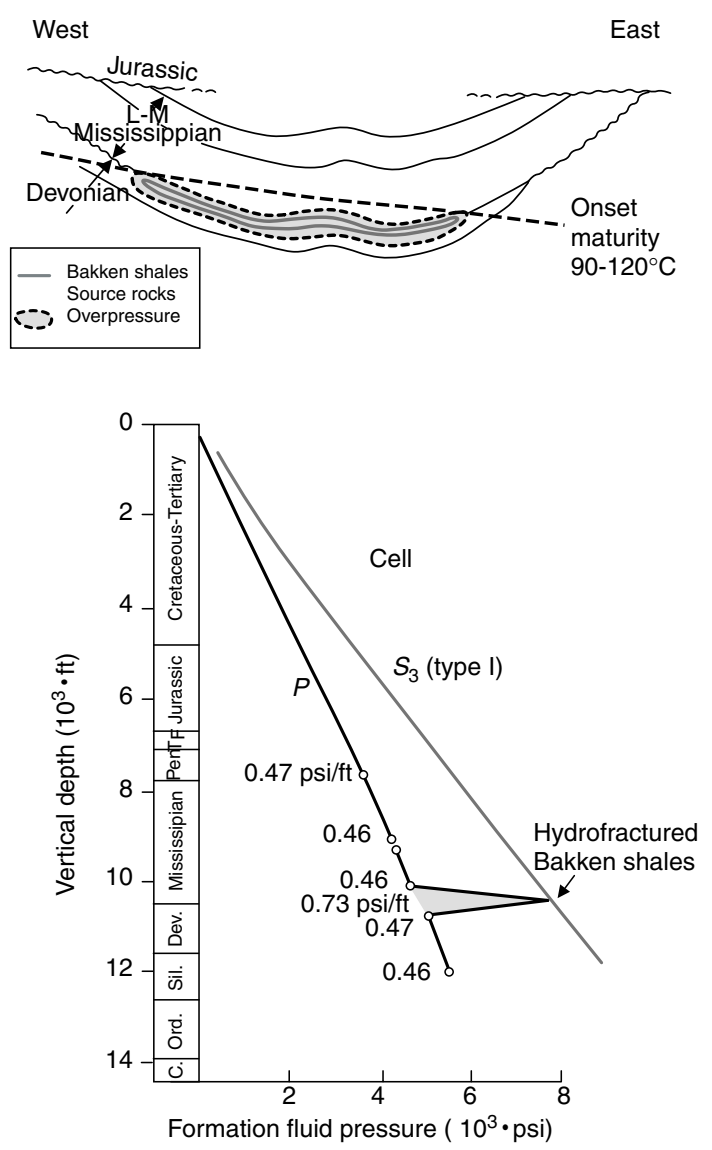

Figure 6

Hydrocarbon generation from Devonian "Bakken shales" source rocks in Williston basin at present-day temperatures ranging from 90 to $120^{\circ} \mathrm{C}$ (from Meissner, 1978). The abnormal pressure cell is restricted to the recently mature source rock interval between 10000 and $11000 \mathrm{ft}$. The pressure gradient, close to $0.73 \mathrm{psi} / \mathrm{ft}$, can be predicted using a $S_{3}$-versus-depth profile normally found in vertical stress dominated areas. 


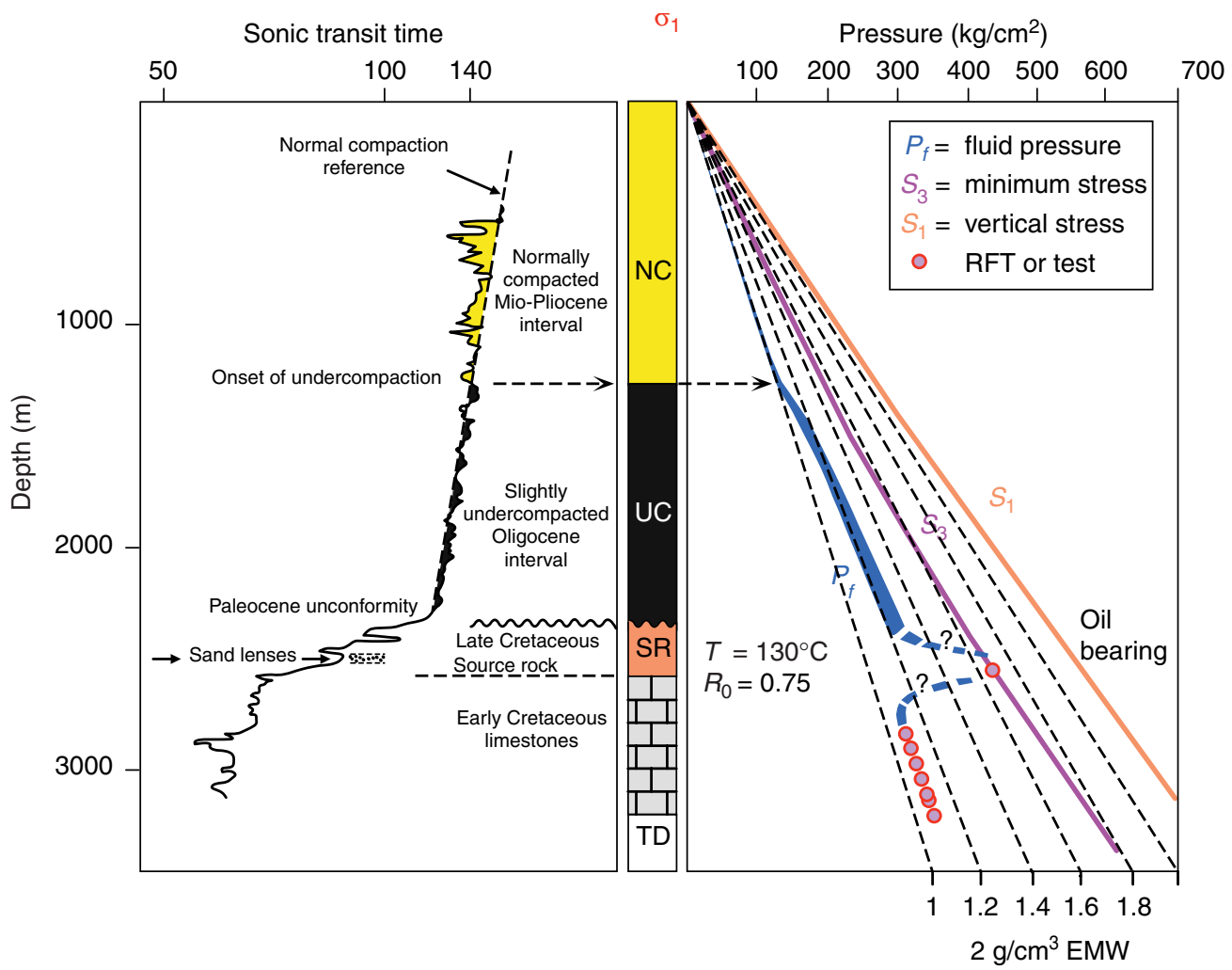

Figure 7

Hydrocarbon generation from Late Cretaceous source rocks in offshore Angola. The abnormal pressure gradient of $1.64 \mathrm{~g} / \mathrm{cm}^{3} \mathrm{EMW}$, especially localized within the source rock interval at $2500 \mathrm{~m}$ depth, well agrees with the $S_{3}$ value, expected in type I vertical stress dominated context. The $130^{\circ} \mathrm{C}$ temperature and the $0.75 \%$ maturity values confirm that the present-day hydrocarbon system is at peak oil generation.

RFT and DST, within a few meters of thick oil-bearing sandy layers, reaches $1.64 \mathrm{~g} / \mathrm{cm}^{3}$ EMW at a depth of $2500 \mathrm{~m}$. As previously, pressure gradients above and below the source rock interval are close to hydrostatic, with values of 1.25 and $1.1 \mathrm{~g} / \mathrm{cm}^{3}$ EMW respectively. The $1.25 \mathrm{~g} / \mathrm{cm}^{3}$ EMW value was estimated through the 1200 to $2400 \mathrm{~m}$ undercompacted Oligocene interval from the sonic log using porosity versus vertical effective stress relationship. The $1.1 \mathrm{~g} / \mathrm{cm}^{3}$ EMW gradient was recorded through the normally pressured saltwater bearing carbonate reservoir below $2600 \mathrm{~m}$. According to the sonic log, the shaly source rocks are overcompacted, and compaction disequilibrium cannot account for the observed high pressure values. A temperature value of $130^{\circ} \mathrm{C}$ and vitrinite reflectance ranging from 0.7 to $0.8 \%$ clearly indicate that source rocks are at peak oil generation at present day. The pressure-versus-depth plot on Figure 7 highlights the excellent agreement between pressure and $S_{3}$ value from type I profile.

\subsection{Multiple Origins}

Overpressure magnitudes are often difficult to be assessed at depth, because different causal mechanisms are frequently involved. In addition, the relative contribution of each mechanism is often unquantifiable. Moreover, the present day "global" overpressure intensity cannot be obtained by summing the different contributions. The two case histories, presented here below, provide good examples of such situations.

\subsubsection{South China Sea - Offshore Brunei}

This offshore sedimentary basin, is characterized by very high sedimentation rates ranging from 500 to $1000 \mathrm{~m} / \mathrm{Ma}$ The cross-section on Figure 8 displays three main domains, from top to bottom:

- A sand-dominated Pleistocene interval down to $1600 \mathrm{~m}$, where hydrostatic regime conditions are related to the high sand to shale ratio, and excellent drainage efficiency. 
- A shale-dominated Pliocene interval down to $2400 \mathrm{~m}$, where the abnormal pressure trend evolves parallel to the vertical stress profile, except within a pinched-out sand layer connected with the fracture network.

- A shalymost deep Late Miocene en échelon-fold structure, characterized by a very high pressure regime (gradient exceeding $2 \mathrm{~g} / \mathrm{cm}^{3}$ EMW or $0.92 \mathrm{psi} / \mathrm{ft}$ ) and hydrofracturing through the 2600-3300 m depth interval (Grauls and Cassignol, 1992). A roll-over type fault system developed on the flank of this structure.

Conventional methods are well suited down to $2400 \mathrm{~m}$ through the undercompacted shaly section, as a result of compaction disequilibrium. However, they cannot account for other causes. The strike-slip fault tectonics (type II) and undrained shear conditions are believed to contribute to the high pressure below $2600 \mathrm{~m}$. That overpressure regime is $25 \%$ in excess of what we can reasonably expect in vertical stress dominated context at such a depth. Pressure values range from 50 to $60 \mathrm{MPa}$ through the 2600-3000 m depth interval, and the pressure trend follows the $S_{3}$ profile corresponding to the type II tectonics (Fig. 5). Hydrofracture conditions maintain the system transiently open at geological time scale, and are very sensitive to slight lateral stress variations. This specific domain is characterized by very high sonic transit time values exceeding $170 \mu \mathrm{s} / \mathrm{ft}$, or interval velocity values less than $1750 \mathrm{~m} / \mathrm{s}$. Such hydrofractured anomalies can be therefore easily detected from seismic velocities interval (Grauls and Cassignol, 1992), and pressure magnitude can be correctly predicted knowing the $S_{3}$ profile related to the present-day tectonic regime. Hydrofracturing processes seem to be systematically associated with compressive strike-slip tectonics, and hydrofracture conditions appear to be preferentially favored during the phases of tectonic relaxation. Such "close to zero" minimum effective periods are also believed to favor episodic vertical fluid transfers from preexisting faults, or from propagation of open fractures under excess fluid pressure. That allowed the hydrocarbon generated below $3200 \mathrm{~m}$ to be transferred upwards to the first available reservoir at $2000 \mathrm{~m}$, during Late Pleistocene time. As shown on Figure 8, at the well location, the migration of large volumes of hydrocarbons in a reservoir of limited extension (undrained conditions) and in a short period of time, caused the fluid pressure increase to a critical value close to $S_{3}$. That demonstrates that the presentday pressure profile is a result of multiple mechanisms: compaction disequilibrium, lateral strain, hydrofracturing, fault related vertical transfers and overcharging in isolated reservoir cell. Therefore, an approach based on $S_{3}$ combined with a good geological understanding, should lead to a better assessment of pressure profile, and hydrocarbon system. However, the pressure transition between undercompacted and hydrofractured zones within the 2400-2600 m depth
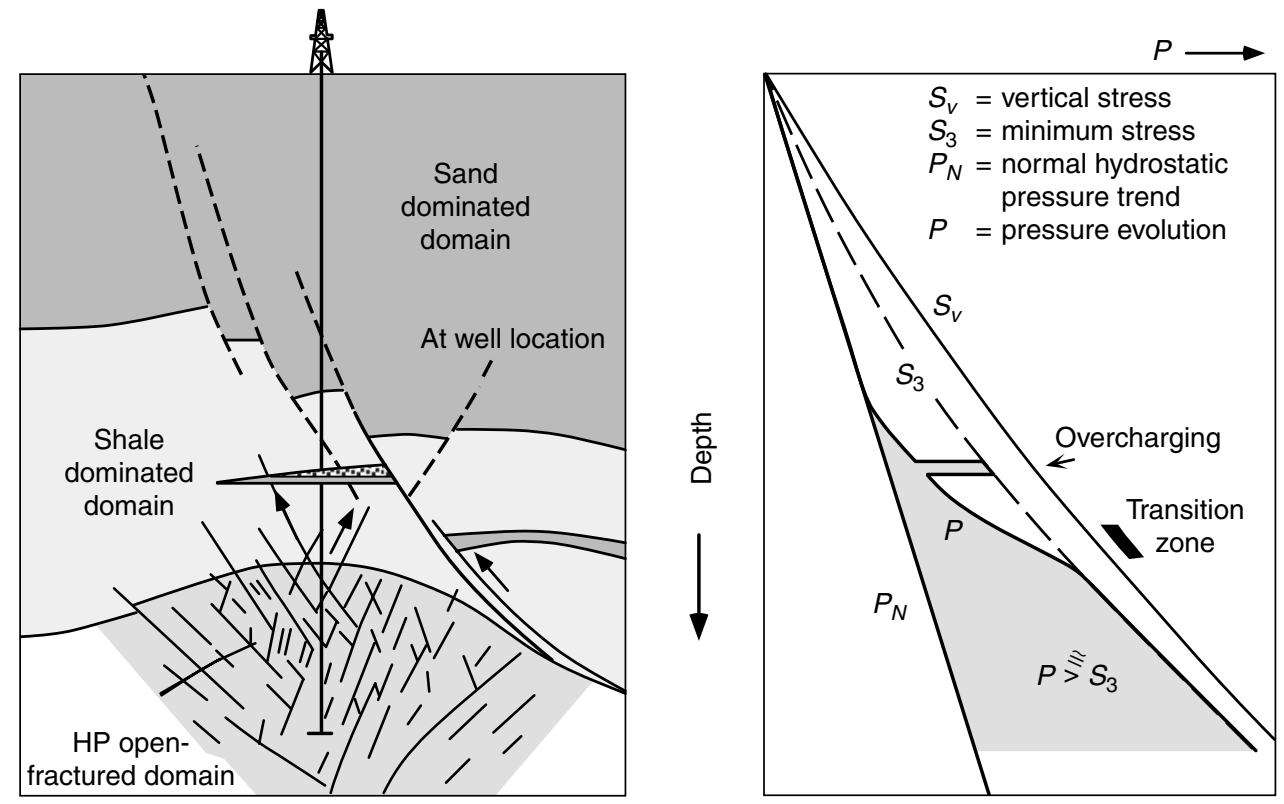

Figure 8

Example from South China Sea: abnormal pressure regimes related to strike-slip fault tectonics, deep hydrofractured domain and to the charging of the above undrained reservoir level, are controlled at depth by in situ minimum stress. Close to zero minimum effective stress $\left(S_{3}-P=0\right)$ conditions allow transient fault and fracture related vertical transfers and charging of the reservoir. 

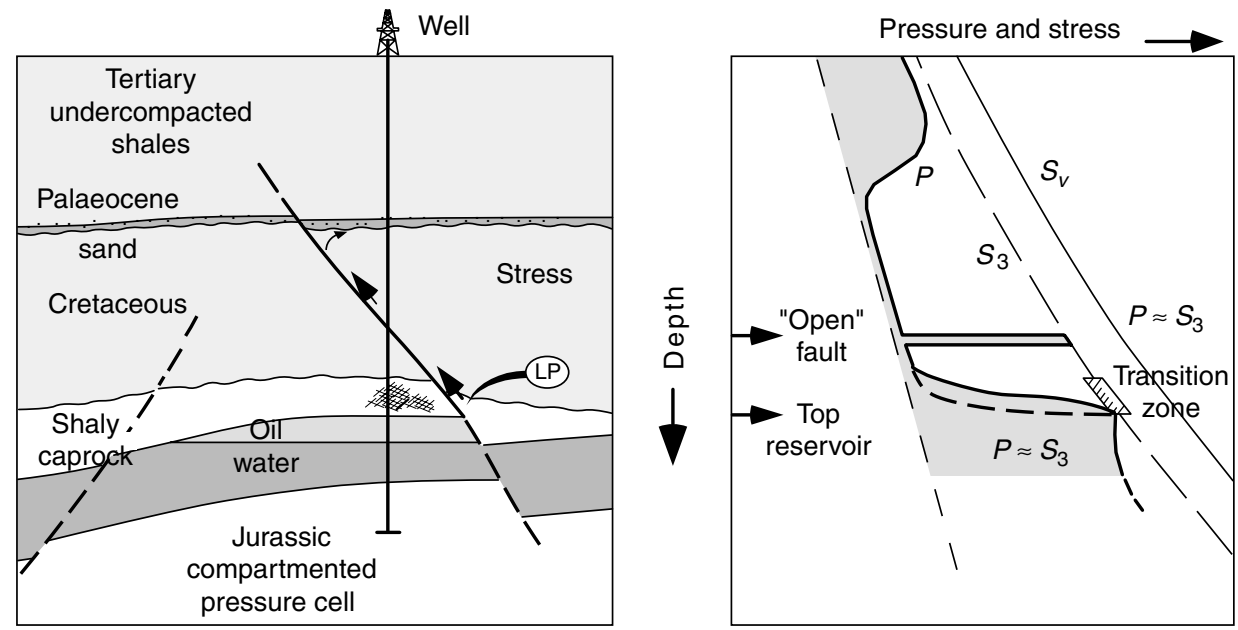

Figure 9

Example from North Sea: abnormal pressures through undercompacted Tertiary section, open fault zone and at top of reservoir compartment are controlled by the minimum stress regime. Leakage (LP) and fault transient behaviour are dependent on in situ minimum effective stress $\left(S_{3}-P\right)$, and account well for vertical hydrocarbon migration from structural highs to Palaeocene sands.

interval was not clearly defined. A better understanding of cap rock sealing properties is required.

\subsubsection{Central North Sea}

As shown on the left hand side of Figure 9, a typical crosssection in central North Sea area allows three main intervals to be successively identified, from top to bottom:

- A shalymost dominated Tertiary section, where maximum thickness reaches $3000 \mathrm{~m}$ and compaction disequilibrium applies. Maximum pressure gradients, close to $1.55 \mathrm{~g} / \mathrm{cm}^{3}$ EMW are encountered at 2000-2500 m depth. The Palaeocene sands act as regional drain and cause the pressure regime to kick back to subhydrostatic regime.

- A normally compacted Cretaceous section down to 4500$5000 \mathrm{~m}$, composed of shales and chalk, where the pressure regime is usually hydrostatic.

- A Pre-Cretaceous section composed by Jurassic and Triassic overpressured reservoirs overlain by Late Jurassic and lower Cretaceous shaly cap-rocks.

The present-day pressure regime in the Jurassic play is essentially due to the high compartimenting of reservoir due to faulting and to rapid burial during Neogene times. In such a closed system, the pressure increased to a maximum value corresponding to the leakage pressure in the highest structural-point pressure cell. Such a value, close to the in situ minimum stress, cannot be accounted for by conventional approaches. The geometry of the compartmented structure conditions the type of leakage. Tilted block geometry favors preferential leakage along the fault. In that case, excess fluid pressure can contribute to the propagation of the fault under hydrofracture conditions. This open or dilatant fault acted as a preferential pathway for episodic hydrocarbon transfer up to the Palaeocene sands. In addition, as highlighted on Figure 9, this open-fault zone, when intersected by an exploratory well, can lead to a sudden pressure increase to a value close to $S_{3}$, within a very short range of a few meters. That can lead to unexpected problems such as unresolved kick, intermediate additional casing setting, lost time, and extra cost. Oppositely, the anticline shape structure favors a leakage through the cap-rock. "Extrados" fractures are reactivated and propagated in mode I, at the apex of structure, forming a pressure transition zone that can be detected from seismic velocities if the interval thickness exceeds $100-150$ ms TWT. In summary, the $S_{3}$ approach contributes to a better understanding of dynamic transfers, and as well to a better assessment of present-day abnormal pressure regimes developed in tectonically multi-phase basins, and resulting from different origins: compaction disequilibrium, compartimenting, faultrelated transfers and buoyancy effect.

\section{LIMITATIONS}

As previously emphasized, the $S_{3}$ approach can be used as a complement to more conventional methods. However, this methodology presents some limitations due to the fact that petroleum systems are never fully open or closed. That intermediate pressure regimes strongly depend on the dynamics of vertical and lateral charging and compartment size. Therefore, assessing overpressures in transition domains 
is more complex. The transition zones are developed both vertically and laterally, and their importance in overpressured systems has already been demonstrated by Swarbrick (1996). The vertical transition zone, as previously emphasized, is more frequently observed at top of anticline structures, and corresponds to an hydrofractured interval indicating a lack of sealing integrity of the overlying cap-rock. The lateral transition zone is more often related to compartment size, drainage area and to the relative efficiency of faults limiting the different compartments. These transition zones are clearly displayed on Figure 10.

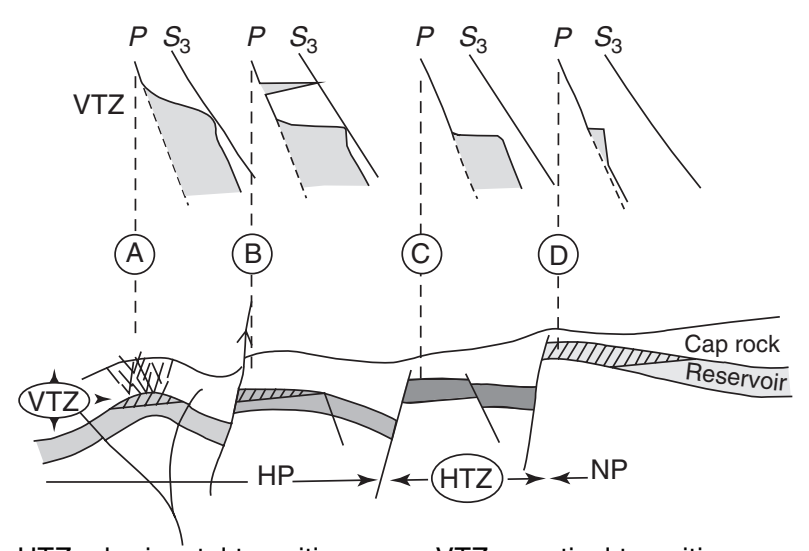

$\mathrm{HTZ}=$ horizontal transition zone; VTZ = vertical transition zone $\mathrm{HP}=$ high pressure domain; $\mathrm{NP}=$ normal pressure domain

Figure 10

Sketch showing lateral transition domain linked to semi-open faulted compartments and vertical transition domains induced by hydraulic fracturing leakage through cap-rock.

In both cases, pressure profiles within transition zones cannot be provided with high accuracy, and additional research on cap-rock and fault seal is still needed to improve their predictability.

\section{CONCLUSIONS}

The general review of main causal mechanisms generating overpressures led to the conclusion that mechanical and thermal stresses along with dynamic transfers are the main causes for generating overpressures in petroleum systems. Some conventional approaches based on porosity versus effective vertical stress relationships have been applied with some success since 1970 in sand-shale Tertiary basins to assess compaction-disequilibrium-related overpressuring, using seismic velocity and basin modeling approaches. However, abnormal pressures cannot be correctly assessed in multiphase sedimentary basins (North Sea), and/or whenever additional causal mechanisms are involved (lateral strain, thermal effect, or dynamic processes). In addition, the present-day fluid pressure profile observed is often the result of several causes acting together, even in sand-shale dominated basins where compaction disequilibrium is assumed to be the only contribution. In these conditions, assessing the magnitude of abnormal pressure regime is almost impossible, as the present-day pressure value cannot be provided by a simple summation of different contributions. A hydromechanic approach based on the parameters controlling the magnitude of abnormal pressures was proposed. This minimum principal stress approach considers that overpressures developed in geologically undrained systems at depth are controlled by rock failure conditions whatever the mode of rupture (mode I, I/II, or II). Such conditions depend on fluid pressure magnitude, rock mechanical properties and deviatoric stress, and occur under very low minimum effective stress regimes $\left(S_{3}-P_{f} \# 0\right)$, or under pressure regimes close to the minimum principal stress $S_{3}$. The $S_{3}$ profile, dependent on tectonic regime, can be quantitatively assessed using a power law function of depth. At a given depth, the $S_{3}$ value increases as the tectonic regime evolves from normal, to strike-slip and thrust fault. Therefore, sound knowledge of present-day geological contexts and tectonic regimes should allow the minimum principal stress profile to be evaluated and, consequently, the pressure regime to be well-assessed. This $\mathrm{S}_{3}$-based approach is well suited to overpressuring induced by lateral stresses, hydrocarbon generation, reservoir compartmenting and overcharging, fault-related dynamic transfers, hydrofracturing, and especially when multiple causal mechanisms are involved in the same area. Such an approach must be considered as a powerful method that can be applied in addition to conventional ones, and does not exclude them anyway. Some limitations, however, must be mentioned. They are due to the fact that hydrocarbon systems are not fully closed or open at depth, and that transition zones or intermediate pressure regimes exist with values in between hydrostatic and minimum principal stress. Better assessment of pressure regimes in vertical and lateral transition domains certainly depends on a better understanding of cap-rock integrity and lateral fault sealing efficiency.

\section{REFERENCES}

Barker, C. (1972) Aquathermal Pressuring: Role of Temperature in Development of Abnormal Pressure Zone. Am. Assoc. Pet. Geol. Bull., 56, 2068-2071.

Berry, F.A.F. (1973) High Fluid Potential in California Coast Ranges and their Tectonic Significance. Am. Assoc. Pet. Geol. Bull., 57, 1219-1249.

Burst, J.K. (1969) Diagenesis of Gulf Coast Clayey Sediments and its Possible Relation to Petroleum Migration. Am. Assoc. Pet. Geol. Bull., 53, 73-93.

Dickinson, G. (1953) Geological Aspects of Reservoir Pressure in Gulf Coast Louisiana. Am. Assoc. Pet. Geol. Bull., 37, 410-432. 
Du Rouchet, J. (1978) Stress Fields, a Key to Oil Migration. Am. Assoc. Pet. Geol. Bull., 65, 74-85.

Fertl, W.H. (1976) Abnormal Formation Pressures, Developments in Petroleum Science, 2, Elsevier, Amsterdam.

Finch, W.C. (1969) Abnormal Pressure in Antelope Field North Dakota. $J P T, 213,170-179$.

Grauls, D. and Cassignol, C. (1992) Fluid Pressure Induced Open Fracture Anomaly. Characterization from Well Data and Seismic Velocities. Mechanisms and Implications. Bulletin Elf Aquitaine, 16, 276-284, December 1992

Grauls, D. and Baleix, J.M. (1993) Role of Overpressures and In Situ Stresses in Fault Controlled Hydrocarbon Migration. Marine and Petroleum Geology, 11, 6, December 1994.

Grauls, D., Dunand, J.P. and Beaufort, D. (1995) Predicting Abnormal Pressure from 2D Seismic Velocity Modeling. Offshore Technology Conference, Paper OTC7692, 525-534.

Grauls, D. (1997) Minimum Principal Stress as Control of Overpressures in Sedimentary Basins. Geofluids II' 97 - Extended Abstracts, Hendry, J.P. (ed.), 219-222.

Harrisson, W.J. and Summa, L.L. (1991) Paleohydrology of the Gulf of Mexico Basin. American Journal of Science, 291, 109-176.

Hedberg, H.D. (1974) Relation of Methane Generation to Undercompacted Shales, Shale Diapirs, and Mud Volcanoes. Am. Assoc. Pet. Geol. Bull., 58, 668-673.

Hubbert, M.K. and Rubey, W.W. (1959) Mechanics of Fluid Filled Porous Solids and its Application to Overthrust Faulting. 1, Role of Fluid Pressure in Mechanics of Overthrust Faulting. Geol. Soc. Am. Bull., 70, 115-166.

Luo, X. and Vasseur, G. (1992) Contributions of Compaction and Aquathermal Pressuring to Geopressure and the Influence of Environmental Conditions. Am. Assoc. Pet. Geol. Bull., 76, 15501559 .
Magara, K. (1978) Compaction and Fluid Migration, Practical Petroleum Geology, Elsevier Scientific Publishing Company.

Mann, D.M. and Mackensie, A.S. (1990) Prediction of Pore Fluid Pressures in Sedimentary Basins. Marine and Petroleum Geology, 7, 55-65.

Meissner, F. (1978) Petroleum Geology of the Bakken Shales Formation, Williston Basin North Dakota and Montana. Proceedings of 1978 Williston Basin Symposium, Montana Geological Society, Billings, 207-227.

Osborne, M.J., Swarbrick, R.E. (1997) Mechanisms for Generating Overpressure in Sedimentary Basins: a Re-evaluation. Am. Assoc. Pet. Geol. Bull., 81, 1023-1041.

Sibson (1981) Controls on Low Stress Hydro-Fracture Dilatancy in Thrust, Wrench and Normal Fault Terrains. Nature, 289.

Spencer C.W. (1987) Hydrocarbon Generation as a Mechanism for Overpressuring in Rocky Mountains. Am. Assoc. Pet. Geol. Bull., 71, 4, 368-388.

Swarbrick, R.E. and Osborne, M. (1996) The Nature and Diversity of Pressure Transition Zones. Petroleum Geoscience, 2 111-116.

Terzaghi, K. and Peck (1968) Soil Mechanics in Engineering Practice. John Wiley and Sons, New York, N.Y.

Traugott, M. (1996) The Pore Pressure Centroid Concept: Reducing Drilling Risks. Abstract, Compaction and Overpressure Current Research, 9-10 December, IFP, Paris.

Yardley, G. (1999) Lateral Transfer: a Source of Extreme Overpressure? Intended for publication in Marine and Petroleum Geology.

Yassir., N.A. (1994) Abnormally High Pressures and Associated Porosities and Stress Regimes in Sedimentary Basins. Eurock'94, Balkema, Rotterdam, 879-886.

Final manuscript received in July 1999 